\title{
SPRUCE-FIR CLIMAX VEGETATION IN SOUTHWESTERN ALBERTA ${ }^{1}$
}

\author{
By R. G. H. CORMACK ${ }^{2}$
}

\section{ABSTRACT}

The present paper describes further the ground vegetation of spurce-fir climax stands in southwestern Alberta.

A small number of "key" plants selected from almost every plant group is shown to be correlated with mature spruce and fir and to delimit sharply this climax stage of coniferous forest succession from all earlier stages.

The stability of spruce-fir stands is briefly discussed.

\section{INTRODUCTION}

An earlier paper (4) recorded a scheme of coniferous forest succession following fire in the mountainous southwest corner of Alberta. This scheme follows Sampson's (8) scheme of range condition classification and attempts to classify obvious stages or degrees of successional development from burn to climax. The various stages are not rigidly fixed but intergrade one with another. In making distinctions between successive stages, the ground cover plants, particularly in the later stages, served as a more reliable criterion than the trees themselves.

While making a survey for the Alberta Game Branch in the same region in 1955 , the opportunity arose to examine further the vegetation of climax stands and to test the correctness of the above mentioned scheme. The present paper presents a brief account of this study.

\section{Observations}

The study area was situated in the Crowsnest Forest Reserve, a large tract of mountainous country in southwestern Alberta. Three widely separated mature spruce-fir stands were selected, all within a few miles of the British Columbia border in the vicinity of the Crowsnest Pass. The first was situated at the head of Dutch Creek, a tributary of the Old Man River about twentyfive miles north of the pass; the second was situated on a small tributary of the Carbondale River about twenty miles south of the pass; and the third was situated at the head of the West Castle River about five or more miles further south.

The stands used in this study were selected because they are welldeveloped examples of coniferous forest as it occurs in this rough mountainous country. White spruce and mountain fir comprise the only tree species with the exception of the occasional Douglas fir and overmature lodgepole pine. The Dutch Creek stand, described in considerable detail by Bloomberg (1) represents the largest remaining block of undisturbed spruce-fir timber in the Crowsnest region. The greatest number of spruce are from 200-300 years old, but younger and much older trees also occur. The pine are almost entirely

\footnotetext{
${ }^{1}$ Received for publication December 14, 1955.
}

University of Alberta, Edmonton, Alberta. Biographical Reference For. Chron. 29(3):218. 
gone and the largest fir are either dead or in a poor condition. In the other two areas logging has been in progress for a number of years, but several good-sized spruce-fir stands still remain.

There is a predominance of tall shade-loving shrubs, and a rich growth of herbaceous flowering plants, horsetails, ferns, mosses, liverworts and lichens. Many species are widespread and have, therefore, little indicator value $(3,4)$. A limited number, however, because of their frequency, abundance and constancy, are obviously characteristic. In the present report, the principal or most characteristic ground cover plants are designated as "key" plants. By far the most striking single feature of climax spruce-fir stands is the dense development of tall shrubs. The "key" tall shrubs are : Menziesia (Menziesia glabella), mountain rhododendron (Rhododendron albiflorum), tall blueberry (Vaccinium membranaceum) and mountain lover (Pachystima myrsinites). These four species occur in all three stands, but mountain lover is definitely the least common. The "key" shrubs mark the limits of the spruce-fir stands more clearly than do any other ground cover plants.

The "key" herbaceous flowering plants are: One-flowered clintonia (Clintonia uniflora), bishop's cap (Mitella pentandra), false mitrewort (Tiarella unifoliata), globeflower (Trollius albiflorus), one-flowered wintergreen (Moneses uniflora), and small flowered wintergreen (Pyrola minor). Others that are restricted to moist or wet places are twisted stalk (Streptopus amplexifolius), Saxifraga arguta, twayblade orchids (Listera spp.) and rein orchids (Habenaria dilatata; $H$. saccata).

Since they do not occur in earlier stages of succession, lady fern (Athyrium filix-femina), and fragile fern (Cystopteris fragilis) are definitely "key" plants. Rush horsetail (Equisetum scirpoides) which forms dense low, creeping mats mixed in with mosses and liverworts is another striking "key" species.

Mosses, liverworts and lichens form a continuous thick green carpet over the soil, boulders, and windfalls. Feather mosses (Hylocomium splendens; Ptilium crista-castrensis; Hypnum schreberi; Rhytidiadelphus loreus; $R$. triquetrus; Rhytidiopsis robusta, etc.) are prominent and common, but mosses with higher water requirements, Mnium mosses (Mnium punctatum; $M$. affine) and several other mosses including Brachythecium rivulare and Thudium abietinum are more characteristic. The trailing delicate leafy liverwort (Barbilophozia lycopodioides) noted before in spruce-fir stands $(3,4)$ but not identified at that time, is frequently the dominant member of the moss carpet and is definitely a "key" plant. The large leafy lichen (Peltigera aphthosa), although it occurs also in less mature stands in which pine are still present, is also characteristic.

In the present study the abundance of the "key" species is shown to have almost as much significance as their presence. This point is well illustrated in the Carbondale River stand where some lodgepole pine are well mixed in with spruce and fir in certain places. Where pine outnumber the spruce, the tall shrub layer is conspicuously thinner and the feather mosses more abundant as compared to parts of the same stand where pine are absent.

The essential similarity of these three stands is based on the combination of all the "key" ground cover plants and not on the presence of any one "key" 
plant or on any one "key" plant group. The combination of "key" plants places all three widely separated stands in the final or climax stage of coniferous forest succession (4).

The observations made during the present study confirm the earlier view (4) that the ground cover plants are important in forest classification. In this regard they agree with the much more detailed observations of Daubenmire (5) for the coniferous forests of Northern Idaho. Moreover, they emphasize the simplicity and stability of the spruce-fir climax stands as pointed out by the writer $(3,4)$ and Bloomberg (1) for this region, and by Oosting and Reed (7) for the Medicine Bow Mountains of Wyoming. If anything, the virgin spruce-fir stands in southeastern Wyoming are simpler in the number of species of ground cover plants and more uniform than our own. There, too, lodgepole pine dominance alternates with spruce-fir dominance in the normal course of coniferous forest succession following fire.

Moss (6), on the other hand, stresses the complexity and instability of both lodgepole pine and spruce-fir stands. With reference to an unpublished report by Horton, he prefers the "continuum" concept for our lodgepole pine forests and considers the climax as a "variable pattern".

The "continuum" concept is adopted from the work of Brown and Curtis (2) and is used by them to describe the upland conifer-hardwood forests of northern Wisconsin. Two more different types of forest would be difficult to find. All the stands described by Brown and Curtis (2) are part of one great community complex. This involves twenty-seven tree species and consists of several pioneer and intermediate stands dominatd by conifers, and unstable climax stands dominated by deciduous trees. The situation in the rough mountainous country under discussion is simple in comparison. Here, coniferous forest succession begins either with pine alone, or with pine and spruce with or without willows and poplar and ends in a stable climax of only two trees, spruce and fir. No two burns are exactly the same in their early stages (4), but barring further fire, the trend from burn to climax is simple and direct.

Variations in spruce and fir content are obvious within and among climax stands $(3,4,7)$. However, the dominance of spruce is clearly indicated, and as far as is known, this dominance will persist. The view expressed by Moss (6) "that alpine fir may be regarded as the culminating species" is not supported by the writer's experience in the Canadian Rockies. In the region under discussion, there are no pure stands of fir. Such would be expected if this assumption (6) were correct.

The writer prefers his own scheme of "successional stages" (4) to describe the East-slope coniferous forest. Not only does it show the important part played by fire in the plant succession of this region, but it has a practical advantage in making a workable forest-site classification.

I wish to thank Mr. E. S. Huestis, Director of Forestry for Alberta, for making the survey possible, and Dr. W. C. Steere, Stanford University, California, for identifying the liverworts and mosses. 


\section{REFERENCES}

1. BLOOMBERG, W. J. 1949. Fire and spruce. For. Chron. Vol. 25: 157-161.

2. BROWN, R. T. AND CURTIS, J. T. 1952. The upland conifer-hardwood forests of northern Wisconsin. Ecol. Monographs. Vol. 22:217-234.

3. CORMACK, R. G. H. 1949. A study of trout streamside cover in logged-over and undisturbed virgin spruce woods. Canad. Jour. Res. C. Vol. 27: 78-95.

4. CORMACK, R. G. H. 1953. A survey of coniferous forest succession in the eastern Rockies. For. Chron. Vol 29: 218-232.

5. DAUBENMIRE, R. 1952. Forest vegetation of northern Idaho and adjacent Washington, and its bearing on concepts of vegetation classification. Ecol. Monographs. Vol. 22: $301-330$.

6. MOSS, E. H. 1955. The vegetation of Alberta. Bot. Rev. Vol. 21: 493-567.

7. OOSTING, HENRY J. AND REED, JOHN F. 1952. Virgin spruce-fir of the Medicine Bow Mountains, Wyoming. Ecol. Monographs. Vol. 22: 69-91.

8. SAMPSON, ARTHUR W. 1949. Application of ecological principles in determining condition of grazing lands. United Nations Vol. 6, Land Resources 509-514. 